\title{
A WAVERING COMMITMENT? ADMINISTRATIVE INDEPENDENCE AND COLLABORATIVE GOVERNANCE IN ONTARIO'S ADJUDICATIVE TRIBUNALS ACCOUNTABILITY LEGISLATION
}

\section{Laverne Jacobs*}

In December 2009, the Ontario Legislative Assembly enacted the Adjudicative Tribunals Accountability, Governance and Appointments Act, 2009 [ATAGAA]. This new legislation offers a unique approach to ensuring that adjudicative tribunals in the province are transparent, accountable and efficient in their operations while preserving their decision-making independence. This approach aims to bring the executive branch of government and tribunals together in acbieving effective and accountable internal tribunal governance. Through the use of illustrative cases, the author argues, however, that the statute does not address many of the contemporary concerns about administrative independence and accountability that tribunals experience on the ground. She argues further that the legislation is inconsistent in its underlying commitment to the concept of accountability itself as it fails to contemplate the importance of government accountability to tribunals and overlooks opportunities to foster sustained internal cultures of accountability. Finally, the approach taken by the legislation must be channeled properly to avoid disintegrating from one of collaborative governance to one of command and control.

En décembre 2009, l'Assemblée législative de l'Ontario a adopté la Loi de 2009 sur la responsabilisation et la gouvernance des tribunaux décisionnels et les nominations à ces tribunaux. Cette nouvelle loi présente une approche tout à fait particulière pour assurer que les tribunaux décisionnels de la province sont transparents, tenus de rendre compte et efficaces dans leur fonctionnement tout en préservant leur indépendance décisionnelle. Cette approche vise à rapprocher l'autorité exécutive du gowvernement et les tribunaux pour en arriver à une gouvernance interne efficace et responsable des tribunaux. En utilisant des cas pour l'illustrer, l'auteure soutient, toutefois, que la loi n'aborde pas plusieurs des préoccupations contemporaines au sujet de l'indépendance administrative et l'obligation de rendre compte dont les tribunaux font l'expérience sur le terrain. Elle soutient de plus que la loi est inconsistante dans son engagement sous-jacent envers le concept lui-même de l'obligation de rendre compte puisqu'elle ne contemple pas l'importance de tenir le gouvernement responsable envers les tribunaux et néglige les occasions de favoriser des cultures internes soutenues de rendre compte. Finalement, l'approche que prend la loi doit être dirigée convenablement pour éviter de se

* Assistant Professor, Faculty of Law, University of Windsor. An earlier version of this article was presented at the Sixth Administrative Law Discussion Forum, Québec City, May 25-26, 2010 and at the $6^{\text {th }}$ Annual National Forum on Administrative Law and Practice, Osgoode Hall Law School, York University, October 18-19, 2010. I am grateful to the participants of the two conferences for their valuable feedback, to Windsor Law students, John Brennan and Melissa Kwok, for their excellent research assistance and to the Law Foundation of Ontario for its generous financial support. 
désintégrer d'une approche de gouvernance collaborative en une de commandement et de contrôle.

\section{INTRODUCTION}

The Adjudicative Tribunals Accountability, Governance and Appointments Act, 2009 $[A T A G A A]$ forms part of a modernization initiative of the current Ontario Liberal government. This initiative aims to strengthen Ontario's laws, regulations and systems by increasing transparency, accountability and efficiency within the province without compromising administrative independence. ${ }^{2}$ The statute is unique in Canada. Ontario is the only jurisdiction that has attempted to address the major public concerns about the accountability of administrative tribunals through one comprehensive, tailored statute. ${ }^{3}$

This paper offers a critique of $A T A G A A$. Through it, I suggest that the legislation has opened the door to certain avenues of ensuring accountability that are potentially quite promising. Specifically, the statute shows an approach to tribunal governance that is collaborative in nature, by providing room for input on a range of tribunal accountability matters from the tribunals that are being governed. $A T A G A A$ fails, nevertheless, to address many critical contemporary concerns relating to tribunal accountability and independence, especially those regarding the accountability of the executive branch of government to administrative tribunals to ensure that the public is adequately served. Of equal concern is that $A T A G A A$ presents an underlying philosophy to accountability that is inconsistent. Despite its attempt at promoting a collaborative governance approach, the statute tends to favour the idea of enforcing accountability from the outside rather than fostering elements of internal tribunal culture that could lead to more authentic and durable measures of accountability.

This paper proceeds in three parts. Part II provides an overview of $A T A G A A$, highlighting its most salient aspects. Accountability and independence are often interwoven in Canadian administrative law. Because their relationship is at the heart of the discussion in this paper, Part III defines these two concepts and discusses the connection between them, placing them within the broader context of the Canadian administrative state. Part IV outlines some of the most significant concerns about administrative accountability that have surfaced in Canadian legal academic literature and recent case law. In this part, I take a focused look at $A T A G A A$. I examine the

$1 \quad$ S.O. 2009, c. 33 Schedule 5 [“ $A T A G A A$," "the $A c t$ ']. $A T A G A A$ received Royal assent on December 15, 2009. It has been coming into force in stages since then. At the time of writing, only the provisions relating to clustering had come into force and no general proclamation date had been set for the rest of the provisions.

2 See Ontario, Legislative Assembly, Ontario Hansard, 179 (27 October 2009) at 1520 (Hon. Christopher Bentley). See also Ontario Attorney General, Press Release, "McGuinty Government Increasing Transparency, Accountability And Effectiveness," (October 27 2009) online: Government of Ontario < http://www.news.ontario.ca/mag/en/2009/10/modernizing-provincial-laws.html>. See also $A T A G A A$, ibid. s. 1.

3 This is not to discount the existence of other statutes in Canada that address, as part of a larger collection of administrative law issues, specific questions of accountability. Of note is Québec's An act respecting administrative justice, RSQ 1998 c J-3, which speaks to certain questions of ethics and accountability. In particular, Title III, ss. 165 - 198, deals with the establishment of a council (Le Conseil de la Justice Administrative) that is responsible for creating a code of ethics for members of the Administrative Tribunal of Québec, for receiving and investigating complaints against members of the Tribunal and for examining issues constituting a lapse in the exercise of administrative office which may lead to the removal of Tribunal members or the Tribunal's President. 
statute's possibilities and limitations with respect to its ability to address contemporary concerns about accountability without encroaching on the equally important value of administrative independence.

\section{ATAGAA: - AN OVERVIEW}

Outside of provisions dedicated to introductory and general matters, ATAGAA addresses the following four main topics: ${ }^{4}$ a) the creation of public accountability documents by adjudicative tribunals and amendments to these documents, b) the creation of governance accountability documents by adjudicative tribunals, c) ensuring merit-based appointments and d) adjudicative tribunal clustering. The following is an overview of how the legislation deals with each of these four topics. Overall, one sees a definite shift towards a sharing of governance between the executive branch of government and adjudicative tribunals. This is a positive step: if properly channelled, it can open the door to allowing for input by a broader spectrum of interests including those of the adjudicative tribunals involved and through them, their users. At the same time, the collaborative governance approach taken by the legislation evidences important gaps that may have an impact on its effectiveness.

\section{A. Public Accountability Documents}

The Public Accountability Documents part of the statute is dedicated to the public face of the adjudicative tribunal. It is concerned with: how the tribunal will conduct itself on a day-to-day basis with the public it serves, how it will handle public complaints, its mission and mandate statements, its ethics plan, and its financial, staffing and training arrangements. These are issues that affect public confidence in how efficiently an administrative tribunal will function and, more indirectly, in the tribunal's adjudicative capacity.

Under $A T A G A A$, every adjudicative tribunal is required to develop a mandate statement and a mission statement, both of which must be approved by the tribunal's responsible minister. However, there is no definition of these statements, no specific content identified for inclusion and there are no guidelines for developing them. Similar provisions are outlined for:

- the tribunal to create a policy for consultation with the public when changing its rules or policies; ${ }^{5}$

- the creation of a service standard policy which indicates the tribunal's intended standard of service and the process for making and responding to complaints about tribunal service;

4 Although it addresses only four main topics, $A T A G A A$ comprises six parts. These six parts are: "Public Accountability Documents" (ss. 3 - 7); "Publication, Amendment and Review of Public Accountability Documents" (ss. 8-10); "Governance Accountability Documents" (ss. 11 - 13); "Appointment to Adjudicative Tribunals" (s. 14); "Tribunal Clustering" (ss. 15 - 19) and "General Matters" (ss. 20 - 22). The legislation ends with a section entitled "Regulations"(ss. 23-25), in which one finds provisions dedicated to the creation of regulations by the Lieutenant Governor in Council and to housekeeping matters such as the coming into force date and short title. The statute, which is short, can be accessed online: Service Ontario e-laws < http://www.e-laws.gov.on.ca/html/ statutes/ english/elaws_statutes_09a33_e.htm>.

5 ATAGAA, supra note 1 at s. 4.

$6 \quad$ Ibid at s. 5. 
- the development of an ethics plan, which must be approved by the public service's Conflict of Interest Commissioner; and

- the establishment of a member accountability framework. ${ }^{8}$

The last of these, the member accountability framework, would appear to be one of the most onerous statements to prepare. It requires the tribunal to provide a description of the functions of all members, vice-chairs and the chair of the tribunal, their skills, knowledge, experience, other attributes and qualifications and that it create a code of conduct for tribunal members. It does not specify what will happen if the code of conduct is breached. It is possible that the tribunal may create its own sanctions, but this is not clear from the statute. The code of conduct requirement is revisited more closely below.

Once drafted, all documents created under the Public Accountability Documents portion of the statute can be amended by the tribunal and must be reviewed every three years by the tribunal to determine if amendments are required.' The Public Accountability Documents part of the statute does not provide explicit rationales or discussion of the underlying goals to be satisfied by each of the various documents required. This is unfortunate as it may render the experience of creating these documents a chore, delegated to the administrative management of the tribunal, rather than a consensus-building exercise among the members and staff of the tribunal.

\section{B. Governance Accountability Documents}

The Governance Accountability Documents provisions of the statute deal with the development of memoranda of understanding between the tribunal and its responsible minister, as well as the creation of business plans and annual reports. $A T A G A A$ requires every adjudicative tribunal to enter into a memorandum of understanding with its responsible minister. ${ }^{10}$ The memorandum should address both the tribunal's internal governance matters and its external relationship with the responsible minister. With respect to internal matters, the memoranda aim to seek agreement between tribunal and minister on questions relating to the financial, staffing and administrative arrangements, committee structure and the recruitment and training of tribunal members. ${ }^{11}$ Such issues are typically left to the discretion of the administrative tribunal. Problems can arise, however, if the executive branch of government interjects without welcome on the tribunal's understanding of how to do things best. One can therefore see how maintaining a pre-established set of guiding norms through a memorandum of understanding can be useful in navigating or avoiding conflicts between tribunals and the executive branch of government. As for the tribunal's external relationship with its responsible minister, $A T A G A A$ merely specifies that the accountability relationships of the tribunal, including its duty to

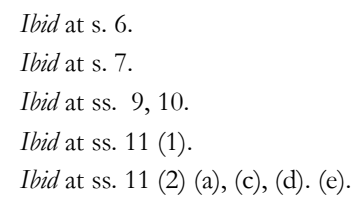


account to its responsible minister should be addressed in a memorandum of understanding. ${ }^{12}$

The preparation of business plans and annual reports are similarly subject to this part of the statute. Every adjudicative tribunal is required to develop a business plan for the public, the contents of which will be prescribed and/or found in a directive of the Management Board of Cabinet ${ }^{13}$ (a committee of the Executive Council which is charged with efficient running of the public service in the province ${ }^{14}$ ). As for annual reports, $A T A G A A$ sets out the timeframe within which annual reports must be submitted to the tribunal's responsible minister, indicates their contents and that they will be tabled in the Legislative Assembly. ${ }^{15}$ Interestingly, the executive branch of government, by way of the Management Board of Cabinet, is able to specify additional matters that should be included in almost every document to be produced by the tribunal in relation to public and governance accountability under the statute.

\section{Appointments to Adjudicative Tribunals}

Undoubtedly in response to persistent concerns about partisanship appointments in the administrative justice system, this part of the statute outlines criteria for ensuring meritorious appointments to adjudicative tribunals. Candidates will be assessed for any tribunal-specific qualifications indicated in enabling legislation, as well as for their experience and knowledge of the law and subject matter, their aptitude for impartial adjudication and their aptitude for applying any alternative adjudicative practices and procedures that may be set out in the tribunal's rules. The recruitment requirements and selection process will be made public. ${ }^{16}$ The chair of the tribunal will be consulted for his or her assessment of a candidate's qualifications and recommendation of appointment. The chair also plays a prominent role in reappointments: he or she will be consulted for an evaluation of current members'

12 Ibid at ss. 11 (2) (b).

13 Ibid at s. 12

14 See Management Board of Cabinet Act, RSO 1990, c M.1 [Management Board of Cabinet Act]. The main purpose of the Management Board of Cabinet is to ensure the efficient operation of the public service in Ontario. The duties of the Management Board of Cabinet are: a) to approve organization and staff establishments in any part of the public service; b) to establish, prescribe or regulate any policies and procedures that the Board considers necessary for the efficient and effective operation of any part of the public service; c) to initiate and supervise the development of management practices and systems for the efficient operation of any part of the public service; and d) to report to the Executive Council on matters concerning general administrative policy in any part of the public service, either on its own initiative or because the matter has been referred to it by the Executive Council (See Management Board of Cabinet Act, ss. 3(1)). The public service is defined broadly to include all Ministries, Crown agencies, corporations owned, operated or controlled by the Crown and all other boards, commissions, authorities or unincorporated bodies of the Crown. Administrative tribunals are generally understood to be independent of the Crown, and at arm's length from central government (which would include ministries of the executive), it is therefore unusual that Management Board, which is fundamentally responsible for Crown operations, would be responsible for creating the directives to guide administrative tribunals in this context. One can certainly surmise that there may be important differences in the way that the regular public service and an arm's length administrative tribunal deal with many of the matters over which Management Board of Cabinet has directive making power. These matters include tribunal mandate and mission statements, public consultation policies, service standard policies, ethics plans and member accountability frameworks.

$15 A T A G A A$ also indicates that if there is a conflict between it and another statute respecting the tabling of annual reports for a particular tribunal, the tribunal-specific statute should prevail. See ATAGAA, supra note 1 at s. 13.

16 See Ibid at s. 14. 
performance of duties and reappointments will only be made upon the chair's recommendation. ${ }^{17}$

\section{Tribunal Clustering}

The idea for tribunal "clustering" in Ontario first emerged as part of a study done in 2007 sponsored by the Ministry of Government and Consumer Services. "Clustering" is defined in the study as a way of sharing best practices among tribunals that work in related areas and deal with related subject matter. The study sought to examine how tribunals could maximize their existing pools of resources to provide the highest level of public service while strengthening individual tribunal mandates. While clustering is not a means of merging or integrating different tribunals into one generic agency and although the aim is not cost-cutting, clustering was seen to be a valuable tool for preserving scarce public resources while retaining specialized expertise. The study looked into the feasibility of clustering certain tribunals dealing with a land use. In 2009, the first tribunal cluster in Ontario was established, the Environment and Land Use Planning cluster. This cluster includes the Assessment Review Board, the Board of Negotiation, the Environmental Review Tribunal and the Ontario Municipal Board.

Through $A T A G A A$, the government has furthered the foundational basis of clustering by setting out guidelines for the designation, governance structure and accountability of clusters. The statute provides that two or more adjudicative tribunals may be designated as a cluster if the Lieutenant Governor in Council (i.e. Cabinet) is of the opinion that they can operate more effectively and efficiently in that way. ${ }^{19} \quad$ No consultation with the affected ministries or tribunals is contemplated in the Act. The Act has provision for an executive chair to be appointed who would be responsible for the entire cluster, as well as for the appointment of various associate-, alternate- and vice-chairs. ${ }^{20}$ The executive chair possesses all of the powers, duties and functions of the chair of each tribunal within a cluster. ${ }^{21}$ As for accountability, the tribunals in a cluster are to participate jointly in the creation of the public and governance accountability documents required under $A T A G A A$.

\section{E. Challenges Arising from $A T A G A A$ 's Choice of Tools and Actors}

With the exception of the tribunal clustering provisions, $A T A G A A$ clearly shows a shift towards a shared model of governance in which both the executive branch of government and administrative tribunals participate in the goal of holding adjudicative tribunals accountable. However, the central question of whether the statute will accomplish its task of assuring the accountability of adjudicative tribunals raises doubts. There are significant gaps in the legislation that reveal conflicting approaches to the legislation's underlying philosophy of collaboration. Four aspects of the legislation reveal its shortcomings. These aspects all centre around the presence or absence of appropriate tools and agents for realizing the statute's objectives.

17 See Ibid at ss. 14 (4).

Final Report of the Agency Cluster Facilitator for the Municipal, Environment and Land Use Planning Tribunals (Toronto: Agency Cluster Project, August 22, 2007) (Facilitator: Kevin Whitaker), online: Ministry of Government and Consumer Services<http://www.gov.on.ca/mgs/graphics/166283 .pdf $>$ [Ontario Agency Cluster Report].

19 See $A T A G A A$, supra note 1 at s. 15.

20 See Ibid at ss. 16, 17.

21 See Ibid at s. 17(1). 
The weaknesses in the legislature's choice of tools and agents of governance appear most readily in the instruments adopted for achieving accountability. These instruments include the public accountability documents and the governance accountability documents. How exactly will the mandate and mission statements, consultation policies, service standard policies, and member accountability frameworks work to ensure that litigants, users and other concerned citizens will be able to hold adjudicative tribunals to account? Many of these instruments are merely descriptive in nature. For example, the mission statements, consultation policies, and member accountability frameworks primarily provide a means for the tribunal to outline functions, skills and policies. Missing are tools that would allow a person alleging that the tribunal has not been accountable to push for some sort of corrective action. It is not clear if these documents are simply bureaucratic instruments or whether they will provide for change.

Even where the legislation does provide instruments that could theoretically engender change, the legislation is silent as to the concrete steps that are to be used to move a tribunal to become more accountable. Discussed briefly above, the provisions requiring adjudicative tribunals to create a code of conduct are illustrative of this shortcoming. Left unstated in $A T A G A A$ is what will happen if a code of conduct, once developed, is breached by a tribunal member. It may be that, in an effort to respect tribunal independence, the legislature has been silent, intending to allow each tribunal to determine whether sanctions should be imposed at all. ${ }^{22}$ If corrective action is contemplated, it is not clear whether the code of conduct is to work with sanctions enforced by an external body such as the responsible minister or the province's Conflict of Interest Commissioner, or to implement penalties developed by the tribunal itself. Some may argue that self-sanctioning is not an effective method; others may suggest that only those within the realm of expertise of the administrative tribunal are in a position to understand well the industry and its workings and to fashion effective disciplinary measures. A final argument might be that the source of any type of penalty is a matter best addressed on a case-by-case basis depending on the nature of the tribunal and the issue in question. All of these options are possible but it is necessary for these and other debates to take place about their merits. $A T A G A A$ does not indicate, however, if or how such discussions will fit into the tribunal's creation of a code of conduct; it merely indicates that a code of conduct must be produced. Finally, sanctions contemplated for noncompliance with the code may be introduced by way of regulation. ${ }^{23}$ If the government chooses to create such regulations, it may be helpful for it to provide tribunals with at least some programmatic guidance on implementation of sanctions, after consultation with the tribunals concerned.

A third shortcoming of the legislation is found in the lack of express rationales for the accountability documents that $A T A G A A$ requires. As mentioned briefly earlier,

22 Legislation that provides remedial or disciplinary measures for tribunal member misconduct may, alternatively, provide for an independent mechanism to deal with sanctions. Under the Canadian Human Rights Act, for example, the Chair of the Canadian Human Rights Tribunal may request the Minister of Justice to decide if a tribunal member should be subject to remedial or disciplinary measures for pre-specified issues of misconduct. The Minister of Justice's options under the statute include holding a public inquiry led by a Superior Court judge and mediation. See the Canadian Human Rights Act, R.S., 1985, c. H-6, s. 48.3.

23 Subsections 23 (h) and 23(i) provide that the Lieutenant Governor in Council may make regulations that prescribe other matters to be addressed or included in any public accountability documents or governance accountability documents, and regulations that prescribe the form and format of these two types of documents. 
such rationales would be useful for any tribunal as it goes about determining how to reach outcomes in developing these instruments. One would hope that the best way to ensure accountability would be to seize the moment when the tribunal has to think through its mandate, mission, service standards etc. and use this moment to foster a consensus-building, reflective exercise among those in the tribunal itself. This would be helpful in encouraging an ethos of accountability among the members of a given tribunal, which could lead to more durable change. If those who must be accountable do not have a meaningful way to engage with the underlying purpose of the accountability instruments they are creating, then the exercise may be a lost opportunity in terms of its resonance within the tribunal itself. Explanations of why the various documents required are necessary may assist in fostering authentic dialogue within the administrative tribunals themselves and in capitalizing on opportunities for the development of an ethos of accountability. As it currently stands, the lack of express rationales comes across as top-down and formalistic, in sharp contradistinction to the collaborative governance philosophy of most of the statute.

It is clear that the legislature's tools of governance leave some quizzical gaps. The same is also true of the choice of agents used to assure $A T A G A A$ 's functioning. Every public accountability or governance accountability document that the tribunals are required to produce is subject to additional directives by the Management Board of Cabinet. Moreover, the responsible minister's approval is required for all documents. These two oversight mechanisms present the opportunity for an unusual amount of control by the executive branch of government. Why does this possibility for executive control exist? One falls into a dichotomous conceptual gap in answering this question, as the premises animating the statute's design are difficult to identify. In creating this statute, was the legislature's intention to touch on matters over which it saw itself capable of legislating or simply to facilitate closer policing of daily tribunal activities in an attempt to prevent and remedy accountability gaps more quickly? Backed with legislative intent, both approaches may be seen to be legally valid. If the main goal, however, is to bring about greater scrutiny over areas that are usually within the administrative control of tribunals then regardless of whether it is legally valid, the statute will suffer from concerns about its legitimacy within the administrative tribunal community.

There are ten main documents that $A T A G A A$ requires tribunals to prepare. ${ }^{24}$ An examination of the language surrounding each one suggests that the legislature still views some of the matters with which the documents deal as areas governed by tribunal discretion, irrespective of the statute's oversight. For instance, each adjudicative tribunal to which $A T A G A A$ applies is required to indicate the standard of service "that the tribunal intends to provide" ${ }^{25}$. Similarly, it is difficult to see how a tribunal mission statement ${ }^{26}$ could be created by the legislature, as mission statements are generally auto-reflective documents that project the values and aspirations developed at the tribunal level. ${ }^{27}$ These elements of $A T A G A A$ suggest that the statute

24 These are the : mandate statement (ss. 2(a)), mission statement (ss. 2(b)), consultation policy (s. 4), member accountability framework (s. 7), service standard policy (s. 5), ethics plan (s. 6), business plan (s. 12), annual report (s. 13), memorandum of understanding (s. 11) and review and amendments to the public accountability documents (ss. 9-10).

25 See $A T A G A A$, supra note 1 at ss. 5(2).

26 See Ibid at ss. 3(2)(b).

27 Similarly, the consultation policy required by the tribunal is dependent on the tribunal chair's opinion as to who should be consulted. See Ibid at ss. 4(2). 
aims to preserve areas of tribunal discretion that fall commonly within the realm of administrative independence ${ }^{28}$ while simultaneously permitting responsible ministers the right to supervise these discretionary realms. ${ }^{29}$ In light of this, it is not surprising that concerns have already been raised by members of the administrative justice community. ${ }^{30}$

Caution should therefore be taken so that approval by the responsible minister, which is required for most of the accountability instruments, does not disintegrate into a command and control exercise over the tribunal's internal governance. Many of the spheres that the statute has now entered were previously fully within the tribunal's administrative control at common law. These include its decisions relating to staffing, training, codes of conduct, service standards and many others. It can be useful to have ministerial input, particularly where this might bring about a more levelled approach to accountability issues among the various adjudicative tribunals in the province." There may be administrative tribunals who currently have few accountability mechanisms in place and others who have already put much time and effort into transparency and accountability. It would be encouraging, however, to see more of a legislated commitment to guard against the possible collapse of the collaborative governance approach proposed in the statute into one of close executive control.

Finally, although $A T A G A A$ aims to make administrative tribunals more accountable, it does not address the countervailing question of the accountability of government to adjudicative tribunals. This accountability is important so that adjudicative tribunals can adequately serve the public. This is a particularly

28 Within the realm of administrative independence, it is administrative control - that is, a tribunal's decision over the daily activities its operation, including managing resources and caseload - which figures most prominently here. For a discussion of the concept of administrative control, see R. $v$. Valente [1985] 2 S.C.R. 673.

29 The legislature clearly has left room for the tribunal's discretion (or the discretion of the tribunal chair) yet also required ministerial approval for the following documents: the service standard policy (see, in particular ss. 5(2) (a)), the consultation policy (s. 4), review and amendment of public accountability documents (ss. 9-10). By contrast, the legislatures are quite unequivocal in indicating the documents for which contents shall be prescribed. These are: the ethics plan (s.6), the business plan (s. 12) and the annual report (s. 13). For these documents, it seems clear that the legislature believes that it could have created legislation on the matter. Finally, there is a gray zone of subjects over which the legislature could take full responsibility but it is not clear from reading the statute that it intended to do so. These include the mandate statement (s. 3) and the member accountability framework (s. 7). The memorandum of understanding (s. 11) is by nature a document of shared responsibility between the tribunal and the responsible minister.

30 See e.g. Ontario Bar Association, “Adjudicative Tribunals Accountability, Governance and Appointments Act, 2009-Cause for Concern: The Independence Issue” (August 25, 2010), online: Ontario Bar Association <http://www.oba.org/En/publicaffairs_en/Submissions/Submissions.aspx $>$. The author discloses being a member of the committee that drafted the report. Some may argue that a responsible minister should have the control of items such as mission statements and consultation policies as part of his or her portfolio. It is hard to reconcile this view of the minister's role, however, with the understanding of an administrative tribunal as an arm's-length agency that is independent of government. As an independent, arm's-length body, the tribunal has been removed from the departments of the executive government and charged with overseeing the management of an industry or sector through its understanding of its enabling statute and its expertise. Documents such as a mission statement or consultation policy emerge from an understanding of the legislation and the day-to-day dealings with the industry or sector that develop over time. Given that the minister is removed from this day-to-day work, it is hard to see how his or her view of documents emerging from a mixture of statutory interpretation and daily tribunal operation can be more appropriate than the perspective of the tribunal itself.

31 ATAGAA currently applies to 37 tribunals in Ontario. The tribunals are listed in the regulation: General O. Reg. 126/10. 
unfortunate failing of the accountability statute. Many concerns about government accountability to administrative tribunals speak directly to tribunal independence. If the legislation had engaged with concerns such as the removal of appointees and budgetary resources, it would have shown a much stronger commitment to balancing accountability and independence in the often politicized operational context of the administrative state. I turn next to a more detailed discussion of the nature of the Canadian administrative state, the values of accountability and independence, and the tense relationship between them, in an effort to show where $A T A G A A$ needs to be strengthened in order to be a truly effective accountability statute.

\section{DEFINING ADMINISTRATIVE ACCOUNTABILITY AND INDEPENDENCE}

\section{A. Institutional Framework - The Canadian Administrative State}

To situate the discussion, it is useful to have a better sense of the bodies with which $A T A G A A$ is concerned. Broadly speaking, the Canadian administrative state refers to the collection of administrative boards, agencies, commissions, tribunals and other similar bodies established at arm's length from the federal, provincial or territorial executive branch of government. These bodies generally receive their mandates through legislation ${ }^{32}$ and their purpose is to help implement government policies and programs. The administrative state aims to "provide a forum that is more specialized, less costly and easier to use than the courts.",

Administrative bodies are said to be "independent" because of the absence of close control over their decision-making by the executive branch of government. "Independence," however, does not indicate a total lack of connection to the executive or legislative branches of government. On the contrary, administrative bodies usually have a designated Minister of Cabinet who is responsible for reporting on their activities to the legislature. The responsible minister also tends to be involved in the appointment of members of the administrative agency and its chair. With respect to legislative connections, administrative bodies are susceptible to having their mandates, structures, and other aspects of their work modified through the legislative process. They may even be abolished through legislative enactment or repeal. $^{34}$

One thing that is clear about the Canadian administrative state is that the term "administrative body" can refer to a wide variety of administrative actors. These actors may vary in their decision-making output. For example, they may produce binding orders (e.g. human rights tribunals), non-binding recommendations (e.g. provincial ombudsman), policy reports (e.g. Royal Commissions) or no reports at all

32 Non-statutory administrative bodies also exist although they are less common. An example is the Anishinabek Police Services, which is an autonomous, self-governing First Nations police service created by agreement among the federal government, the Ontario Government and a number of First Nations groups (the Anishinabek Police Service Agreement 1992). See the discussion of the Anishinabek Police Service in McDonald v. Anishinabek Police Service (2006), 53 C.C.E.L. (3d) 126. Nonstatutory administrative bodies are generally described as being created through Crown (executive) prerogative.

33 Ontario, Everyday Justice: Report of the Agency Reform Commission on Ontario's Regulatory and Adjudicative Agencies (Toronto: Queen's Printer for Ontario, 1998) at 3.

34 See e.g. Wells $v$. Newfoundland, [1999] 3 S.C.R. 199 in which a member of a public utilities board lost his position and pension rights when the Newfoundland government restructured the board and terminated his appointment. The Supreme Court of Canada held that the member was entitled to compensation from the government for the breach of its obligations. 
(e.g. a body with no statutory duty to give reasons may refrain from doing $\mathrm{so}^{35}$ ). Administrative bodies are also not distinguished by the nature of the disputes they hear. They hear disputes between private parties (e.g. labour boards), between individuals and government (e.g. social benefit tribunals) or larger polycentric matters that address issues such as government planning and energy distribution. External structure is yet another factor that is not consistent among administrative bodies. Although most are created as extensions of the executive branch of government, some are agents of the legislature. ${ }^{36}$ Similarly, the structure of administrative bodies may range from multimember organizations to a single cabinet minister. ${ }^{37}$ The appointment process and terms of appointment may also cover a broad range of options, varying as to whether all of the political parties have a say in the appointment of the chair or members or whether it is an appointment by the government of the day; whether the appointment is for a fixed length of time or is an appointment at the pleasure of the government; and whether there is a statutory procedure for removing an appointee. ${ }^{38}$ As for the internal structure of administrative tribunals, this element often depends on the discretion of the chair of the agency in conjunction with those who work there. The internal organization of administrative bodies (e.g. how many departments there are, how the departments will divide the work, etc.) is not uniform, owing largely to the differences in function of various tribunals. Even tribunals with similar policy goals across the country may have very different internal structures. Empirical evidence shows that the internal structure and internal culture (the norms or ethos that guide the work that is done at the tribunal) similarly manifest themselves in large variety.

Finally, the procedures of administrative bodies may be vastly different. Some administrative bodies have court-like processes, others may decide disputes in a much less formal manner, still others may provide the opportunity to be heard through a written hearing and some employ inquiry powers. Reflective of this broad and seemingly unwieldly array is that among the many official names for administrative actors, one will find "agencies," "boards," "commissions," and "tribunals" although no one name denotes any particular mixture of decision-making output, nature of dispute, structure or procedure.

35 However, the common law duty to give reasons may apply if the decision will have a significant impact on the individual(s) affected. See Baker v. Canada (Minister of Citizenship and Immigration), [1999] 2 S.C.R. 817.

36 The most typical examples of administrative actors that have been established as officers of the legislature are the ombudsman, which exist in nine of the provinces and territories, and access to information and privacy commissioners which exist in eleven provinces and territories as well as at the federal level. See e.g. the Ontario Ombudsman Act R.S.O. 1990, c. O.6 and the Freedom of Information and Protection of Privacy Act, R.S.B.C. 1996, c. 165.

37 See generally on the wide definition of the term "administrative actor," W. A. Bogart, "The Tools of the Administrative State and the Regulatory Mix" in Colleen M. Flood \& Lorne Sossin eds., Administrative Law in Context (Toronto: Emond Montgomery, 2008) [Administrative Law in Context].

38 Terms of appointment and removal may require a formal review by Parliament or the legislature and approval by a percentage of Parliament or the legislature. See e.g. An Act respecting Access to documents held by public bodies and the protection of personal information, RSQ c A-2.1, ss. 104, 107 which indicates that a member of Québec's access to information and privacy commission may be appointed and dismissed only on a resolution of the legislature that is approved by not less than two-thirds of the Québec legislative assembly. Most administrative contexts do not require such formal review.

39 Laverne Jacobs, Fashioning Administrative Independence at the "Tribunal" Level: An Ethnographic Study of Access to Information and Privacy Commissions in Canada (Ph.D. dissertation, York University, Osgoode Hall Law School, 2009) [unpublished] [Fashioning Administrative Independence]. 
A few distinct responses to the diversity of the administrative state have emerged in administrative law theory. The courts, certain legal academics and some commentators have developed a classification of administrative bodies according to their degree of resemblance to the courts. This school of thought proposes that administrative bodies should be conceived as running along a spectrum. ${ }^{40}$ Considered to be at the adjudicative end of the spectrum are administrative actors that make decisions affecting individual rights, that serve primarily to determine a lis between parties by adjudicators who are appointed by government and then chosen by the chair to preside alone or on panels, and that employ procedures that are quasijudicial nature (i.e. that involve oral hearings, the exchange of evidence, submission of legal argument, etc.). The spectrum theory maintains that adjudicative bodies should provide the highest degree of procedural fairness for the parties who appear before them. "Some also maintain that the expression "tribunal" be reserved for bodies that fit this end of the spectrum. ${ }^{42}$ At the opposite end of the spectrum are administrative bodies that primarily produce governmental policy. These bodies may hear from a multitude of perspectives in determining how government should act in cases that are not individual but systemic. Individuals appearing before policy oriented bodies are said to require less procedural fairness. Between the two polar ends of the spectrum run a range of tribunals that vary in their mixture of policy and adjudicative functions. The spectrum approach to categorizing the actors of the administrative state has captured the attention of certain policymakers. Indeed, in some jurisdictions such as Ontario, these concepts have been adopted as organizational tools. The Public Appointments Secretariat of Ontario, for example, classifies agencies into eight different types, drawing distinctions, among other things, between "advisory agencies" which create policy and "adjudicative agencies" which are quasi-judicial dispute resolution bodies. ${ }^{43}$

The spectrum school of thought has been challenged by those who argue for a less disaggregated understanding of the work of administrative bodies. In its most robust form, the theory put forth by these scholars maintains that instead of focusing on what appears to be the most dominant function that an administrative body performs, a more authentic understanding of the administrative state would

40 See e.g. David J. Mullan, "Administrative Tribunals: Their Evolution in Canada from 1945 to 1984" in Ivan Bernier and Andrée Lajoie, eds, Regulations, Crown Corporations and Administrative Tribunals (Royal Commission on the Economic Union and Development Prospects for Canada, vol. 48) (Toronto: University of Toronto Press, 1985); Canadian Bar Association, Task Force Report, Independence of Federal Administrative Tribunals and Agencies in Canada (Ottawa: Canadian Bar Association, 1990) (Chair: Edward Ratushny, Q.C.); Bell Canada v. Canadian Telephone Employees Association, [2003] 1 S.C.R. 884 [Bell Canada]. That the notion of a spectrum underpins much administrative law theory can be gleaned from authors who seek to build upon the theory such as $\mathrm{S}$. Ronald Ellis, "The Justicizing of Quasi-Judicial Tribunals Part I" (2006) 19 Can J Admin L \& Prac 303, and others who denounce the theory such as Roderick A. Macdonald, "The Acoustics of Accountability: Towards Well-Tempered Tribunals" chapter 6 in András Sajó (ed.) Judicial Integrity (Leiden: M. Nijhoff Publishers, 2004) at 141-180.

41 See e.g. the Supreme Court of Canada's assertions to this effect in Bell Canada, ibid. and in Nenfoundland Telephone Co. v. Nenfoundland (Board of Commissioners of Public Utilities), [1992] 1 S.C.R. 623.

42 See e.g. the use of the term in Kaye Joachim, "New Models in Administrative Hearings: The Human Rights Tribunal of Ontario" in Ronalda Murphy \& Patrick A. Molinari, eds, Doing Justice: Dispute Resolution in the Courts and Beyond (Montréal: Canadian Institute for the Administration of Justice, 2009) at $87-110$.

43 See "What Is an Agency" online: Ontario Public Appointments Secretariat < https://www.pa s.gov. on.ca/scripts/en/general-Info.asp>. Similarly, in Québec, the word "tribunal" is reserved for designated entities including "any person or agency exercising quasi judicial functions." See Charter of human rights and freedoms R.S.Q., c. C-12 at ss. 56. 
acknowledge that every administrative body performs a range of tasks, often incorporating some form of decision-making, policy-making and many other functions such as investigation, education, auditing etc.. ${ }^{4}$ The implications of this approach are felt most significantly when considering the issues of procedural fairness and accountability. Those who critique the spectrum approach, are generally wary of associating degrees of procedural fairness and accountability with only the most dominant function of an administrative body. Instead, they propose that issues such as procedural fairness and accountability are best addressed through a close understanding of the nature and work of each individual agency. Most recently, there has also been emerging literature which posits that each agency's internal culture and informal normative order can play a significant role in establishing barometers for fairness and accountability. ${ }^{45}$

Quite in conformity with Ontario's general adoption of the spectrum theory, ATAGAA's focus is on adjudicative tribunals. The statute itself does not define "adjudicative tribunals;" rather, the administrative bodies to which it applies are named in a schedule.

\section{B. The Concepts of Administrative Accountability and Independence}

The aim of the ATAGAA, 2009 is to strike an appropriate balance between accountability measures imposed on adjudicative tribunals and non-interference with the tribunal's decision-making. The desire to strike this balance is reflected in the Act's first section which reads:

The purpose of this Act is to ensure that adjudicative tribunals are accountable, transparent and efficient in their operations while remaining independent in their decision-making. . $^{77}$

The public and the administrative tribunal community have expressed an enormous amount of concern over the accountability and independence of administrative actors. ${ }^{48}$ Accountability speaks to the requirement that an agency and its members show responsibility for their actions. A general understanding is that there should be some way to ensure that administrative actors are not misusing public funds and that they are using their resources efficiently. The notion of administrative accountability extends past financial and timeliness concerns, however, to address other qualitatively important areas such as the ethics, subject-matter competency and performance results of appointees. The central questions surrounding accountability are: to whom should an administrative body and its members be held accountable? For what

44 See Macdonald, supra note 40

45 See Macdonald, ibid.; Jacobs, Fashioning Administrative Independence, supra note 39.

46 See $A T A G A$ A, supra note 1, s. 2 and Ontario Reg. 126/10.

47 ATAGAA, supra note 1.

48 There have been numerous reports written on reforming the administrative justice system that touch on accountability and independence. In Ontario, these reports include: Directions: Review of Ontario's Regulatory Agencies (Report prepared for the Management Board of Cabinet) (Toronto: Queen's Printer for Ontario, 1989) (Chair: Robert Macaulay) and Everyday Justice, supra note 33. There have also been documents produced by tribunal member associations dedicated to professionalization and professional development that address these issues from a tribunal perspective. See e.g. British Columbia Council of Administrative Tribunals, Report on Independence, Accountability And Appointment Processes In British Columbia Tribunals, British Columbia Council of Administrative Tribunals Policy and Research Committee Report by Philip Bryden and Ron Hatch, 2009, online: British Columbia Council of Administrative Tribunals < http://www.bccat.net/assets/downloads/indrep.pdf >. 
activities should they be held accountable? And through what mechanisms should accountability be measured?

Ensuring that the tools used to garner accountability do not simultaneously infringe on the administrative actor's independence is another crucial concern that arises often in the context of Canadian administrative law and policy. The concept of administrative independence refers to safeguarding decision-makers from improper interference or influence. The theory goes that by ensuring this freedom, there is a greater likelihood that decisions will be based solely on the law and evidence. Independence is therefore a tool for guaranteeing impartiality. Placed in the context of arm's length administrative bodies, independence is usually considered in light of the degree to which adjudicators have the promise of security of tenure, financial security, institutional control and freedom in their adjudicative deliberations. Interference by the executive branch of government, another tribunal member, staff, litigants or any other entity is held to arise when a reasonable person would perceive one or more of these factors to be compromised. ${ }^{49}$ Regardless of what the reality may be, the reasonable person test requires only that a reasonable perception of lack of independence exist for there to be a breach of procedural fairness. ${ }^{50}$ As well, while the factors of security of tenure, financial security, institutional control and adjudicative independence are similar for both the judiciary and administrative bodies, a key distinction between judicial and administrative independence is that the degree to which independence is required for administrative bodies can vary, depending on the intention of the legislature and the institution's nature and functions. ${ }^{51}$

\section{EXPLORING TENSIONS BETWEEN ADMINISTRATIVE ACCOUNTABILITY AND INDEPENDENCE: ILLUSTRATIVE CASES}

Situations in which accountability and independence conflict often stem from the de facto development of on-the-ground relationships between the administrative body and the branch of government to which it is required to report; they may also arise between members of the administrative body itself. To demonstrate how conflicts between accountability and independence emerge, I use the three central questions identified earlier - namely, "accountability to whom?" "accountability for which activities?" and "accountability through what measures?" as a framework for examining illustrative examples of problems that have occurred recently in the jurisprudence or on the ground. These illustrations also serve as a backdrop to my analysis of $A T A G A A$ 's potential as an administrative accountability tool. I argue that $A T A G A A$ could be a statute of greater impact if it were to draw on lessons learned from these past situations.

49 See the seminal cases of R. v. Valente, supra note 28 at paras. 24-26 and Beauregard v. Canada, [1986] 2 S.C.R. 56 at para. 21. On the test for reasonable perception of partiality, see Committee for Justice and Liberty v. National Energy Board [1978] 1 S.C.R. 369 at 394-5. The test, although formulated in dissent, has since been applied consistently by the Supreme Court as the appropriate approach to be taken.

For greater discussion of the concept of independence, see Laverne Jacobs, "Independence, Impartiality and Bias" in Administrative Law in Context, supra note 37 and Laverne Jacobs, "Tribunal Independence and Impartiality: Rethinking the Theory after Bell and Ocean Port Hotel: A Call for Empirical Analysis" in Laverne A. Jacobs \& Justice Anne L. Mactavish., eds., Dialogue Between Courts and Tribunals: Essays in Administrative Law and Justice (2001-2007) (Montreal: Les Éditions Thémis, 2008) at 43-66.

51 See Ocean Port Hotel Ltd. v. British Columbia (Gen. Manager Liquor Control), [2001] 2 S.C.R. 781. 


\section{A. Administrative Accountability: Accountability to whom?}

Administrative actors are generally said to be accountable to four entities: to the branch of government through which they report to the legislature, ${ }^{52}$ to the legislature itself, to the public, and to themselves. The first of these contexts has offered the most challenge in the jurisprudence and on the ground.

\section{Accountability to the executive branch of government}

As for accountability to government, $A T A G A A$ 's framework does not capture some of the most problematic situations. Such circumstances of accountability have arisen when the executive branch of government has attempted to assume control over the administrative body's decisions. These instances raise the delicate question: to whom is the agency rightfully accountable? In these cases, authority for the interference by the minister or the executive branch of government can seldom be linked legitimately to a legislative enactment. Frequently, legislation has been misused in a thinly disguised attempt to assert executive control; alternatively, the inappropriate situation arises simply from an informal, on-the-ground relationship that an agency and the executive have developed.

One of the sharpest examples of attempted executive control occurred in 2007 when the President of the Canadian Nuclear Safety Commission, Linda Keen, was removed from her position following a decision that had plainly displeased the Minister of Natural Resources. ${ }^{53}$ The Canadian Nuclear Safety Commission regulates all nuclear facilities and activities in Canada with the purpose of ensuring their compliance with health, safety, security and environmental standards as well as fulfilment of Canada's international obligations..$^{54}$ In 2007, the Commission decided to keep closed a nuclear power plant that had been temporarily shut down for routine maintenance because of its failure to meet safety standards. This nuclear reactor, however, was also a primary source for the production of medical isotopes used in health care in the country and around the world. The closure therefore caused a shortage of isotopes. Eventually, in order to circumvent the effects of this decision, Parliament enacted legislation reopening the reactor. This was an appropriate legal avenue to take given the doctrine of parliamentary supremacy. This legislative step was taken, however, only after the Minister had attempted to use other means to influence the President and Commission's decision.

The chronology set out by the Federal Court in Keen indicates that the Minister participated in a Saturday conference call with the President and members of the Commission in which he requested a hearing be convened immediately in order to approve the restart of the reactor. ${ }^{55}$ This followed a prior conference call between the Minister, the Commission and the operators of the reactor at which the Minister urged the Commission and the licensee to work together to resolve the issue. Finally, the Minister took advantage of a directive power provided in the Commission's enabling statute to craft a directive that appeared specifically tailored, by its wording and timing, to force the Commission to decide in favour of the licensee. Under the enabling statute, the directive power allows only for directives of "general application

\footnotetext{
52 I will use the term "legislature" to denote both provincial legislatures and the federal parliament for ease of convenience.

53 See Keen v. Canada (Attorney General), [2009] F.C.J. no. 402 [Keen].

54 See Nuclear Safety and Control Act, S.C. 1997, c. 9, s. 9. More information about the Canadian Nuclear Safety Commission can also be found online: Canadian Nuclear Safety Commission $<$ http://www.nuclearsafety.gc.ca/eng/>.

55 See Keen, supra note 53.
} 
on broad policy matters" to be issued to the Commission. ${ }^{56}$ Yet, this directive, which was prepared by the Minister two days after the Saturday conference call, required the Commission to take into account "the health of Canadians who, for medical purposes, depend on nuclear substances produced by nuclear reactors" in the course of its regulation..$^{57}$ In light of the ongoing live litigation, one could argue that it was invalidly created. The Bill requiring the reactor to be reopened was enacted the next day and was enacted before the President of the Commission had even received the directive.

About two weeks after all of these events had occurred, the Minister wrote to the President of the Commission, asking her to explain why certain evidence had not been taken into account in the Commission's decision-making and why the directive issued by his office had been ignored. ${ }^{58}$ He also expressed disappointment in her leadership of the Commission and indicated a loss of confidence in her abilities. Finally, his letter indicated that he was considering asking for her removal as President before her term was up. ${ }^{59}$ This, in fact, is what eventually happened. Although she responded to the Minister's letter, Ms. Keen was removed by Order-inCouncil before she had an opportunity to respond to the concerns at a Parliamentary investigation set up for this purpose. Her removal was upheld on judicial review in the Federal Court. ${ }^{60}$

Overall, the Minister's interaction with Ms. Keen was set in tones that revealed a strong misperception of the relationship between his office and the Commission. While the Minister is responsible for reporting to Parliament on behalf of the Commission, the Commission as an arm's length independent body is not responsible for accounting to the Minister for the decisions that it makes. One of the reasons for the establishment of administrative tribunals was to remove political influences on decision-making, leaving decision-making to those with expertise in a particular subject matter. Even if the Commission's decision had inappropriately overlooked evidence, that was a matter for judicial review, not for review by the executive branch of government. There were no provisions for any type of review by the executive in the Commission's enabling statute. Finally, it is plain that there may be situations where it is in the public interest to remove the head or a member of an administrative tribunal. It would be more appropriate, however, for the parameters surrounding

56 With respect to directives from Cabinet to the Canadian Nuclear Safety Commission, s. 19 is the relevant provision. It reads:

DIRECTIVES

$19 . \quad 1$ ) The Governor in Council may, by order, issue to the Commission directives of general application on broad policy matters with respect to the objects of the Commission.

(2) An order made under this section is binding on the Commission.

(3) A copy of each order made under this section shall be

(a) published in the Canada Gazette; and

(b) laid before each House of Parliament.

$57 \quad$ See Keen, supra note 53 at para. 25.

58 See Letter from Minister Lunn to Linda Keen (on file with author) and partial reproduction of the letter in Keen, ibid at para. 29.

59 See Keen, ibid.

60 Ibid. The Federal Court held that Ms. Keen's appointment as President was an at pleasure appointment and that her opportunity to respond to the minister's letter satisfied any procedural fairness obligation that may have been owed to her. 
removal to be governed clearly by legislation or memoranda of understanding that has put a process in place proscriptively.

In Keen, the Minister simply took it upon himself to get involved in the Commission's decision-making process on this one particular file. This is an example of what I earlier described as a de facto relationship that developed on the ground. It is not the only instance in which there has been a clash between the executive branch of government and an administrative body over decisions made by a tribunal. ${ }^{61}$ Unfortunately, these improper callings to account undermine confidence in the government of the day and generate confusion over what is and is not appropriate behaviour for the tribunal (i.e. should the President of the Nuclear Safety Commission have had medical treatment as a top priority in considering what to do about the unsafe reactor?) which can also affect public confidence in the administrative justice system.

If a situation like this were to occur in Ontario, $A T A G A A$ might offer some recourse but only if management at an astute tribunal had found a way to incorporate preventive measures in a memorandum of understanding that gained approval by the responsible minister. What is clear is that the legislative branch of government in Ontario has not taken it upon itself to flag this type of behaviour as an issue. It has not highlighted possible attempts by the executive branch of government to interfere with tribunal decision-making under the guise of tribunal accountability to the executive as a concern - even though the stated purpose of the Act is to increase administrative accountability while avoiding conflict between accountability and independence.

\section{Accountability of the executive branch of government to administrative tribunals}

In what ways can a lack of accountability by the executive branch of government hinder the work of administrative tribunals? Accountability on the part of the executive branch of government implies respecting the express or implied commitments that host ministries have towards their arm's length agencies and fulfilling them in good faith. The ultimate concern that the public be adequately served by administrative tribunals depends on the fulfillment of such commitments. Building on the discussion of removals from the last section, one should note that even in circumstances when a chair or member of a tribunal has been statutorily removed through non-renewal of his or her term of appointment, one may wonder if ministerial discretion has been exercised in good faith. An example that speaks well to this idea deals with the Military Police Complaints Commission, an administrative body which has been prominent in the media of late. ${ }^{62}$ A second example examines the detrimental effects of providing insufficient budgetary resources through a look at a recent situation with the Commission for Public Complaints against the Royal Canadian Mounted Police [RCMP].

61 See generally Lorne Sossin, "The Puzzle of Independence" (2009) 26 NJCL 1 in which he discusses some of the major incidents in recent years.

62 Another example that deals with the removal of tribunal members relates to the Saskatchewan Labour Relations Board. However, in the Saskatchewan case, legislation had been enacted that explicitly allowed for the changing of tribunal members upon the election of a new government. See Saskatchewan Federation of Labour v. Saskatchewan (Attorney General, Department of Advanced Education, Employment and Labour) 2010 SKCA 27, affg 2009 SKQB 20. 


\section{(a) Military Police Complaints Commission}

The Military Police Complaints Commission [MPCC] is a federal adjudicative administrative tribunal. Its mandate is to provide civilian oversight of police matters by investigating complaints made about the conduct of military police, to hold public hearings, to report on its findings, and make recommendations to senior officers in the Canadian Forces, the Deputy Minister of National Defence and/or the Minister of National Defence. ${ }^{63}$

Peter Tinsley chaired the MPCC from September 12, 2005 to December 12, 2009. When his appointment, which was for a four-year term, ended, it was not renewed. During the time of his appointment, he was instrumental in having an investigation started into the question of whether the Canadian Forces had transferred detainees to Afghanistan despite the risk of torture. The federal government, which was a respondent to the allegations, refused to cooperate in providing the relevant documents for the hearing to proceed, claiming national security privilege. This led to a protracted ongoing debate..$^{4}$ A new chair, Glenn Stannard, was appointed to continue the hearing. Yet, his appointment raised questions about continuity of the process as he had not participated in the initial part of the proceedings. ${ }^{65} \mathrm{He}$ also did not have the legal background that the former chair possessed.

The fact that the government of the day was both in charge of the appointment and removal process for members of the MPCC and concurrently appearing as a party before the MPCC, cast doubt over the neutrality of Cabinet in replacing Mr. Tinsley. Even if Cabinet's actions were legal under the enabling legislation, a reasonable person who takes into account the battle that the MPCC has had to obtain the relevant documents from the government party, including being taken on judicial review, may have a reasonable apprehension of bias. Circumstances seem even more unusual, when one takes into account that the new chair has no legal training, in contrast to Mr. Tinsley.

It seems that in cases such as these where the independence of the decisionmaking body has the potential to be influenced indirectly, it would be best to have a mechanism put in place that helps neutralize the reappointment process. In this regard, $A T A G A A$ shows a positive, first step. One recalls that $A T A G A A$ requires the executive to seek the chair's recommendation of members who are up for reappointment. In this way, $A T A G A A$ shows a commitment to shared governance in the appointments process. However, a fuller commitment would also provide the tribunal with the opportunity to give input when the executive branch of government is considering whether to reappoint the current chair. This input could be given by a

63 See National Defence Act, R.S., 1985, c. N-5, Part IV. More information about the Military Police Complaints Commission can also be found online: Military Police Complaints Commission $<$ http://www.mpcc-cppm.gc.ca>. proceedings, on Oct. 30, 2008, the government filed for judicial review, arguing that the MPCC did not have jurisdiction over general military operations but only over "policing duties and functions." It argued that transferring detainees was a general military operation and therefore not subject to scrutiny by the Commission. On March 24, 2010, the Commission ruled that the hearings would continue. The new Chair, Glenn Stannard, who had been interim chair after Peter Tinsley's appointment was not renewed, was appointed to this position on May 14, 2010. A parallel proceeding in Parliament is also taking place which currently has led to the sharing of the relevant documents amongst a contingent of members of Parliament who represent all parties in the House of Commons.

65 See transcript of proceedings, October 14, 2009, which lists those present at the hearings, available online: Military Police Complaints Commission <http://www.mpcc-cppm.gc.ca/300/afghan/indexeng.aspx $>$. 
designated committee of the tribunal and could be offered automatically whenever a chair's term faces the possibility of renewal under the enabling legislation. A further useful procedure could be to require that reasons be given by the executive branch of government on the replacement or reappointment of the chair. This would offer greater transparency and accountability to the process. Reasons would also assist if judicial review were sought of the executive's decision. Again, while $A T A G A A$ shows the beginning of a collaborative governance approach, strengthening the legislation in this way would provide a more engaged commitment to accountability by both the tribunals and the executive branch of government. It may also stave off some of the ill-effects that have already occurred to the public's confidence in the administrative state.

\section{(b) Commission for Public Complaints against the RCMP}

A second brief example relating to the accountability of the executive to administrative tribunals concerns the obligation to provide sufficient funding for tribunals to do their work. Although it may seem obvious, situations have occurred in which funding has been removed part way through a project, causing the project to be disbanded. This occurred recently to the Commission for Complaints against the RCMP [Commission] which is a federal oversight body that takes complaints against the RCMP. The Commission conducts investigations and also has research and policy-making functions. ${ }^{66}$ After several tragic incidents had occurred involving the use of conducted energy weapons (or "tasers") by RCMP officers, the Commission initiated an inquiry into taser use by the RCMP. It received money from the government for a long-term study and produced two reports. However, its funding was cut quite suddenly in 2009. Some commentators have linked the funding cut to the critical stance that the Commission has taken of the RCMP. ${ }^{67}$ Regardless of whether some sort of reprisal might have been involved, the point is that by not living up to its funding commitment and not explaining itself, the government engendered a loss of public confidence in the administrative justice system.

$A T A G A A$ may not speak directly to the specifics of ensuring budgetary resources but it does require the "financial, staffing and administrative arrangements for the tribunal" ${ }^{168}$ to be addressed in a memorandum of understanding with the responsible minister. This is definitely a useful step that can be further developed by tribunals and ministers on a case-by-case basis. It will be up to the tribunals to ensure that they have sufficient resources and it would be wise for them to create measures that allow them to receive additional resources easily should they find themselves short in the middle of a fiscal year. Ideally, having a clear and transparent mechanism in place should also avoid potential apprehensions of inappropriate contact, especially when the government is a party before the tribunal or somehow subject to the tribunal's scrutiny.

66 See Royal Canadian Mounted Police Act R.S.C., 1985 c. R-10, Part VI. Section 45.32 of the RCMP Act addresses the duties of the commission. However, these duties are set in very broad parameters. There is no specific indication of all duties in the statute.

67 See e.g. "Report slams RCMP in airport Taser death," CBC News (8 December 2009) online: CBC news $<$ http://www.cbc.ca/canada/british-columbia/story/2009/12/08/bc-kennedy-vancouverairport-taserreport.html\#ixzz0iwj7uv4d $>$.

68

ATAGAA, supra note 1. ss.11 (2). 


\section{B. Administrative Accountability: Accountability for what Activities?}

Do administrative tribunals have an obligation to provide feedback to the executive branch of government about how the legislation it administers has been faring? This question speaks to the very nature and purpose of administrative tribunals. In Ocean Port Hotel, the Supreme Court of Canada held that administrative tribunals exist primarily to implement the policies of the executive branch of government. As Chief Justice McLachlin held in discussing the distinction between administrative tribunals and courts, "[a]dministrative tribunals, by contrast, lack this constitutional distinction from the executive. They are, in fact, created precisely for the purpose of implementing government policy."

If tribunals are created to further the policies of the executive branch of government as set out in legislation, it would seem sensible that establishing channels of feedback to the executive on the success and challenges of the legislation should not be problematic. However, this issue came to a head in 2004 when the Alberta government sought the input of the Alberta Labour Relations Board on legislative amendments that it was making to the Alberta Labour Relations Code. ${ }^{71}$ In the case of Communications, Energy and Paper Workers Union of Canada, Local 707 v. Alberta (Labour Relations Board $)^{72}$ several unions and the Alberta Federation of Labour applied for judicial review alleging that there had been inappropriate contact between the executive branch of government and the labour board. The unions believed that the legislative changes had a negative impact on collective bargaining rights. Further complicating matters was that the legislation had been developed by the government in what seemed to be a shroud of secrecy, as there was no consultation with the unions.

The fact that the executive branch of government had consulted with the labour board during the creation of the legislative amendments was not revealed directly to the unions. The unions and the Federation of Labour discovered what had occurred by way of freedom of information requests. The scope of the application for judicial review was also unusual - the applicants sought certiorari of all current and future decisions pertaining to the legislation. The ground of review invoked was reasonable perception of insufficient independence and impartiality on the part of the Board visà-vis the executive.

The Alberta Queen's Bench held that the consultation did not give rise to a reasonable apprehension that the Board lacked independence or impartiality in its decision-making. The court fixed particularly on the fact that there were no live cases dealing with the legislation taking place at the time of the consultation. This was not enough for the Alberta Federation of Labour, however, which understandably suffered a grave loss of confidence in the Alberta labour relations regime. In the end, the Labour Board developed guidelines setting ground rules for any future legislative consultations it may have with the executive. ${ }^{73}$ The guidelines touch both on the

69 This section draws from an earlier work - see Laverne Jacobs, "Reconciling Independence and Expertise within the Expert Multifunctional Tribunal" (unpublished paper).

70 Ocean Port Hotel, supra note 51 at para. 24. See also Bell Canada, supra note 40, in which the Supreme Court of Canada attempted to classify certain tribunals as having greater or lesser policy-making functions.

71 R.S.A. 2000 , c. L-1.

722004 ABQB 63.

73 See Alberta Labour Relations Board, Labour Relations Board Guidelines for Consultation on Legislation (29 March, 2007). 
process that will be taken in its relationship with the executive and to the ways in which affected parties will be notified.

There is certainly a legitimate role for administrative tribunals to play in the ongoing development of the legislation they administer. Nonetheless, they should be accountable to their public users for the manner in which they interact with the executive branch of government on legislative consultations. Lessons can be learned from the guidelines developed by the Alberta Labour Relations Board. The guidelines stress the importance of using legislated channels, such as any provisions that may exist in enabling legislation allowing for the Minister to ask the tribunal to conduct research on a specific matter, before turning to informal contact. ${ }^{74}$ The guidelines also emphasize transparency and provide that consultation responses will be made publicly available. ${ }^{75}$ The fact of consultation will equally be revealed by any member who was involved at the beginning of a hearing in which the legislation is at issue so that the parties may decide if the board member's recusal is necessary. ${ }^{76}$ At the moment, $A T A G A A$ deals only with consultation between a tribunal and public users with respect to changes in policies and procedures. Given that the enabling legislation for various tribunals may be piecemeal in addressing the concerns that arise around consultation between the executive branch of government and an administrative tribunal on legislative changes, it would be helpful for $A T A G A A$ to incorporate some of the guidance from the Alberta Labour Relations Board experience.

\section{Administrative Accountability: Through what Measures?}

The discussion thus far has looked at the potential misuse of de facto relationships that develop between a tribunal and the executive branch of government. This final section considers de facto relationships of accountability that may emerge between the chair of the tribunal and tribunal members and considers ways to safeguard against the encroachment on adjudicative independence that could arise. A particular way that this challenge has occurred in Canadian administrative law jurisprudence is through the use of internal performance evaluations.

Outside of asking for reasons for a decision, there has been an increased interest in evaluating the performance of members through performance assessments. At present, some tribunal chairs conduct internal assessments of individual members, although there is no uniform approach to the issue. ATAGAA speaks of an assessment to be done by the chair at the time when members' appointments are up for renewal. This information is shared with the responsible minister. Indeed, reappointment cannot take place unless the chair has done this assessment and provided a positive recommendation to the minister.

However, problems relating to independence have occurred in the context of member performance evaluations. The leading case on this issue in Canada is Barreau de Montréal v. Québec (Procureure Générale)" which dealt with mandatory performance evaluations for members of the Administrative Tribunal of Québec [TAQ] that once existed under the Québec Act respecting administrative justice. ${ }^{78}$ TAQ is an adjudicative

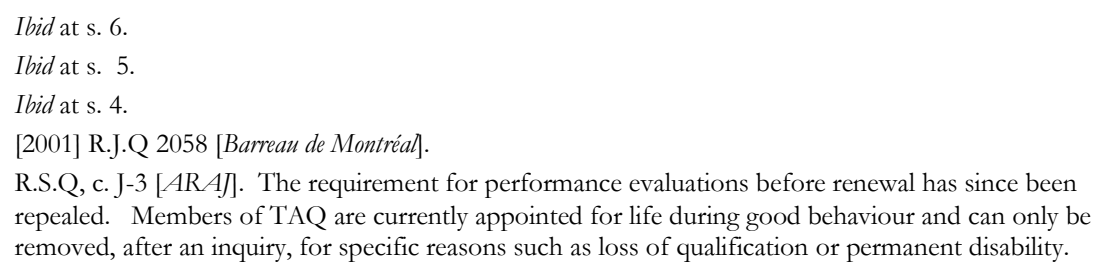


administrative appeals tribunal that hears appeals from a large number of tribunals in Québec. At issue was whether the performance evaluation method provided in TAQ's enabling legislation contravened the requirements of an independent and impartial decision-making process under the Québec Charter." The evaluation was to be conducted by a committee of tribunal members that included the President of TAQ as well as a representative of the executive branch of government.

It was argued that the requirements for members of TAQ to undergo a performance evaluation in order to receive salary increases raised a reasonable perception of infringement on their security of tenure. The concern was that having the head of the tribunal involved in performance evaluations could result in members deciding cases to please the chair instead of deciding cases in good conscience. It was further argued that the presence of a government representative as a member of the committee responsible for conducting the appraisal gave rise to a reasonable apprehension that the government could interfere in the adjudicative independence of the members. The government is always a party before TAQ and one might perceive that members whose decisions do not please the government could end up being evaluated poorly. The court agreed with these arguments, emphasizing not only the apparent lack of independence, but also the fact that the statute did not provide members under evaluation an opportunity to be heard about the recommendations put forward by the committee.

Viewed in light of the approach adopted in $A T A G A A$ which requires all members up for renewal to be evaluated by the chair, it would seem wise to take heed of the cautionary tale provided by the Barreau de Montréal case. The requirement for an assessment before renewal should remain. Having the tribunal's input on whether to renew members is obviously important to assure that competent individuals are appointed. At the same time, it is difficult to think of a method that can guarantee against members under evaluation seeking to please the evaluator. Possibly, having evaluations performed by an external independent body (as is currently done with $\mathrm{TAQ}^{\mathrm{s}}$ ) may assist with the perception that decision-makers are deciding independently when one party before them has a connection to the evaluator. I believe, however, that the most important lesson that can be taken from the Barrean de Montréal case is that having an opportunity to respond to recommendations to renew can lend accountability and transparency to the process in much the same way as was discussed above in relation to the removal of tribunal chairs.

\section{CONCLUSION}

The Good Government Act, of which $A T A G A A$ forms a part, was developed after consultation with 22 government ministries. There is no evidence, however, that administrative tribunals themselves were consulted in the creation of the statute. ${ }^{81}$

See $A \mathrm{R} A J$, ss. 51-54. An excellent overview of the history of TAQ is provided in France Houle, "A Brief Historical Account of the Reforms to the Administrative Justice System in the Province of Québec" (2009) 22 Can J Admin L \& Prac 47.

79 Section 23 of the Québec Charter of Human Rights and Freedoms, R.S.Q., c. C-12, applies to all quasijudicial bodies in Québec. This section reads: "Every person has a right to a full and equal, public and fair hearing by an independent and impartial tribunal, for the determination of his rights and obligations or of the merits of any charge brought against him."

80 See Houle, supra note 78 at 70-71.

81 Both the debates in the legislative assembly as well as the background press material released by the Attorney General referred to consultation with 22 government ministries. There is no indication of consultation with adjudicative tribunals. 
Perhaps it is not surprisingly, then, that $A T A G A A$ could have been strengthened through a stronger engagement with the on-the-ground concerns of administrative tribunals.

Many of the contemporary conflicts between the values of accountability and independence stem from de facto relationships that were developed inside administrative tribunals or between tribunals and government. These relationships have either gone wrong or there is a reasonable perception that they have gone wrong. ATAGAA attempts to address the question of accountability solely by requiring tribunals to account to government. $A T A G A A$ 's failing, however, is that it ignores the concomitant obligation on government to be accountable to administrative tribunals and, by extension, to the public. ${ }^{82}$ Questions relating to the removal of appointees, budgetary resources, legislative consultation and performance evaluations are all issues for which $A T A G A A$ shows little or no appreciation. Yet, they are administrative justice issues that have caused the public to lose confidence in the recent past. As well, while $A T A G A A$ is strong on sending directions to administrative tribunals to account, it is weak on facilitating methods for tribunal accountability to be fostered as an ethos at the tribunal level. Finally, there are no safeguards to protect the collaborative governance approach that $A T A G A A$ proposes from collapsing into one that functions through executive control. Until these aspects are fixed, $A T A G A A$ will remain only a wavering commitment to the very concept of accountability that it promotes.

82 One could also mention that $A T A G A A$ does not address the concern of whether administrative tribunals achieve their intended purpose, an issue that is explored by Lorne Sossin and Steven Hoffman in their contribution to this special issue. See "The Elusive Search for Accountability: Evaluating Adjudicative Tribunals" (2010) 28:2 Windsor YB Access Just. 